\title{
Impact of Social Innovation on Innovation and Business Growth in Mexico
}

\author{
Angie-Lorena Riaño-Castillo ${ }^{1}$, Gonzalo Maldonado Guzman ${ }^{2}$, Ruben Michael Rodriguez González ${ }^{1}$, Sandra \\ Yesenia Pinzón Castro ${ }^{1,3}$ \\ ${ }^{1}$ Centro de Ciencias Económic as y Administrativas, Universidad Autónoma de Aguascalientes, Aguascalientes, \\ México \\ ${ }^{2}$ Centro de Ciencias Económicas y Administrativas, Departamento de Mercadotecnia, Universidad Autónoma de \\ Aguascalientes, Aguascalientes, México \\ ${ }^{3}$ Centro de Ciencias Económico Administrativas, Decana del Centro de Ciencias Económicas y Administrativas, \\ Universidad Autónoma de Aguascalientes, Aguascalientes, México \\ Correspondence: Angie-Lorena Riaño-Castillo, Centro de Ciencias Económico Administrativas, Universidad \\ Autónoma de Aguascalientes, Aguascalientes, México.
}

\author{
Received: March 26, 2021 \\ Accepted: April 28, 2021 \\ Online Published: May 12, 2021 \\ doi:10.5539/ibr.v14n6p59 \\ URL: https://doi.org/10.5539/ibr.v14n6p59
}

\begin{abstract}
The development of social innovation activities is a relatively recent topic in the innovation literature, and is increasingly gaining the attention of researchers, academics, and industry professionals. However, little has been written about the relationship between social innovation, service innovation activities and the level of growth of service companies, so this research aims to fill this gap in the literature to through an extensive review of the literature. Likewise, a self-administered questionnaire was distributed to a sample of 300 service companies in Mexico, analyzing the data set through confirmatory factor analysis and structural equation models.
\end{abstract}

Keywords: social innovation, service innovation, growth, service companies

\section{Introduction}

In the scientific literature in the field of innovation, various researchers, academics, and industry professionals have considered innovation activities as one of the most critical and most relevant factors in business studies (Afriyie, Du, \& Abdul-Azzis, 2019). This type of activity is fundamental not only to overcome the financial and economic crisis, but also to promote the growth and productivity of any type of organization. (Organisation for Economic Co-operation and Development [OECD], 2005, 2009, 2010). Innovation is generally considered as a necessary activity and a continuous process in the sector of the global economy that offers public services from the redistribution and provision of health care to education, generating companies with access to information and new markets. (OECD, 2005; Vanderhoven, Steiner, Teasdale, \& Calò, 2020).

The Sustainable Development Goals (SDGs) in the 2030 Agenda point out the importance of innovation, and even more so grounded in a social sphere, because it faces the various challenges to accelerate progress and contribute to ending poverty and poverty. hunger; guarantee inclusive health and education; achieve gender equality, sustainability, and climate action; support action and innovation at the local level (Aksoy, Alkire (née Nasr), Choi, Kim, \& Zhang, 2019; Naciones Unidas, 2020a). Similarly, the 2030 Agenda indicates that innovation is a requirement of "transformation of the financial, economic and political systems that govern our societies today to guarantee the human rights of all" (United Nations, 2020b, p. 2). For this reason, not only the collaboration of the government is required, but also the participation of the companies that attribute the main activities of production and consumption of products and services. (Aksoy et al., 2019).

In addition, companies that offer services and that are in permanent interaction with modern society, have a main role to face these challenges, promote and successfully implement the SDGs through social innovation. (Aksoy et al., 2019) that in the face of a "financial and economic crisis, it makes creativity and innovation in general, and social innovation in particular, even more important to promote sustainable growth, guarantee employment and increase competitiveness" (OECD, 2010, p. 195). That is why there is a growing interest by the government, foundations, researchers, and academics from around the world in deepening the topic of social innovation, due 
to the lack of an established, common, and shared concept, especially in the field of social change. (Montgomery, 2016; D'Amario et al., 2020; Vanderhoven et al., 2020).

In this sense, it is common to find in the literature in the field of innovation that service companies can promote the advancement of social innovation and generating significant benefits, which allow companies to achieve a higher level of growth. (Aksoy et al., 2019). In this context, the main contribution of this study is the analysis and discussion of the effects that social innovation exerts on the innovation and growth activities of service companies in an emerging economy country, such as Mexico, such as and as recommended by Aksoy et al. (2019) and D'Amario et al. (2020), in addition to providing important empirical evidence that complements the incipient research on this area in quantitative studies (D'Amario et al., 2020), and contributes to the generation of knowledge of the social impact (Aksoy et al., 2019).

Additionally, this study also seeks to answer the following research question: what is the impact of social innovation on service innovation and on the level of growth of companies in Mexico? To complement and answer this question, the rest of the document is structured as follows: in the second section, the published studies will be announced and the hypothesis raised; in the third section, the methodology used is presented; the fourth section presents analysis and interpretation of results and finally, sixth section, conclusions.

\section{Literature Review}

\subsection{Theoretical Approaches to Research}

Social innovation requires leaders who empower, take risks, and expect failure to be part of the process while fostering new ideas (Aksoy et al., 2019). Therefore, Schumpeterian theory suggests that "the social economy is characterized by an entrepreneurial regime in which radical and infrequent innovations are carried out mainly by heroic individuals and leaders of young companies, while incremental innovation is viewed with greater prominence in established large companies, which favor rapid growth " (Desmarchelier, Djellal, \& Gallouj, 2020, p. 1). In addition, social innovation through creativity, empowerment, and leadership, can achieve the development of solutions and optimization of existing resources to foster sustainable growth, increase competitive capacities, secure employment, promote social change and economic recession (BEPA, 2010; Aksoy et al., 2019).

Likewise, social innovation is not exclusive to non-profit organizations, it can be developed in any type of company, for example, Boston Consulting Group offers its consulting services to promote and support social innovators that are consistent with the mission of the business (Desmarchelier et al., 2020), while Standard Bank in South Africa, through $0.2 \%$ of the independent trusts of small and medium-sized companies, finances loans for entrepreneurs, which increases the number of entrepreneurs with capital and decreases the poverty rate. Judson Manor in Cleveland, Ohio offers an innovative service by generating a free life for college students in exchange for meaningful interactions with senior citizens, and Tablée des Chefs in Canada provides surplus food from hotels and restaurants to food shelters (Aksoy et al., 2019).

Consequently, "companies generate wealth that can address poverty and hunger, and even universal access to education" (Aksoy et al., 2019, p. 442), they are the engine of our world and their services are socially innovative (Aksoy et al., 2019). Likewise, it identifies and reflects on difficult social and emotional experiences, improves social outcomes to increase well-being and participation in services, and supports vulnerable people, generating learning and guidance services for the community (Millar, Steiner, Caló, \& Teasdale, 2020; Vanderhoven et al., 2020), addressing social inequalities (Vanderhoven et al., 2020). Thus, "social innovation contributes to changing behavior in different institutional settings, through markets and public sectors, and to improving responsible inventiveness from the bottom up towards the integration of social networks, economic and environmental objectives. (Soma, Van de Burg, Hoefnagel, Stuiver, Van der Heide, \& Martijn, 2018, p. 363).

\subsection{Social Innovation and Service Innovation}

The tertiary economy has modified the economic environment with the generation of service innovation known as the generation of "new services introduced to satisfy an external user or market need" (Damanpour, 1991, p. 561), generally which is considered as an agile market strategy that is present in market services, manufacturing companies and public administrations (Desmarchelier et al., 2020). Furthermore, social innovation is conceptualized as "the application of innovative, practical, sustainable and market-based approaches to benefit society in general, and low-income populations in particular" (World Economic Forum, 2016, p. 5 ), therefore, the essence of social innovation "can be seen as a new governance approach that involves broader actors in the design and delivery of services aimed at addressing social needs" (Vanderhoven et al., 2020, p. 1).

Therefore, social innovation can be developed in any organization, from for-profit companies, to companies with 
new hybrid models (Phillips, Lee, Ghobadian, O'regan, \& James, 2015; Aksoy et al., 2019), becoming an essential criterion not only for social entrepreneurship to execute social and environmental missions (Kraus, Niemand, Halberstadt, Shaw, \& Syrja, 2017), but also to significantly increase the various opportunities through the social intrapreneurship of companies for service innovation (Aksoy et al., 2019), the which would particularly entail obtaining more and better business results that would facilitate the development of social change inside and outside the organizations (Davis \& White, 2015).

In this sense, social innovation in service companies is conceptualized by D'Amario et al. (2020, p. 109) as the "introduction of a new good or service or one significantly improved in terms of its characteristics or uses to meet social objectives", while Aksoy et al. (2019, p. 429) conceptualized it as "the creation of innovative, scalable and sustainable market-based service offerings that solve systemic social problems of society". Consequently, service companies that have adopted and implemented a social innovation, can present a significant growth in the different innovation activities that they develop in a social context. (Vanderhoven et al., 2020).

Therefore, the success of social innovation in service companies depends on a deep understanding of the needs and modus operandum of local communities (Desmarchelier et al., 2020), since it can generally generate different benefits, such as create a high level of trust between the client and the brand, adapt to the existing resource and environmental problem, track and report performance metrics, contribute to the growth of companies, from the generation of new markets and innovative value offers, to sustainable supply chains in the production and creation of value for the consumer (Desmarchelier et al., 2020), which contribute to social well-being (Aksoy et al., 2019).

However, there are multiple causes that delay the level of growth of social innovation in a social economy due to low levels of secrecy and patent protection; social pursuit, rather than profit (the non-profit nature); the combination of codified (not understandable) and technical knowledge with a complex set of social skills; the difficulty of replicating solutions (Desmarchelier et al., 2020); and, the risk that the mission of the organization itself deviates when it grows or strays too far from its ultimate goal: the community (Vanderhoven et al., 2020). Thus, according to the information previously presented, it is possible to propose the following research hypothesis:

\section{H1: Social innovation has a significantly positive relationship with service innovation.}

\subsection{Social Innovation and Growth}

Social innovation favors different institutional environments and participates in the energy, aquaculture, tourism, mining and biotechnology sectors, which contributes to increasing employment and economic growth while taking care of the environment (Soma et al., 2018). Now, an important characteristic of the economic growth of service companies is innovation, which favors increased productivity (Baumol, 2002; Desmarchelier et al., 2020). Furthermore, investment in service innovation allows companies to survive in a highly competitive environment (Baumol, 2002). The presence of incremental innovation compared to radical innovation rapidly favors productivity growth in business environments (Desmarchelier et al., 2020), and the execution of an innovation routinely under this environment contributes to sustained economic growth (Baumol, 2002).

Likewise, the growth of service companies not only refers to economic optimization and the effective and efficient use of resources, but is also related to the creation of changes in the social and environmental context (Soma et al., 2018 ), because the depletion of resources and environmental degradation that world society is losing, directly affects both the economy of service companies and the economy of society in general, therefore, the adoption and implementation of social innovation activities, potentially favors the economic growth of service companies, in a particular way, and the economy of society, in a general way (Reilly, 2012; Soma et al., 2018).

Likewise, "social innovation is related to the principle of sustainability for the economic growth of companies and countries, triggers innovation beyond the purposes of innovation exclusively based on profit and seeks long-term solutions" (Soma et al., 2018, p. 363), which generates as benefits the growth of innovative value offers, of the market and of sustainable supply chains in the generation of services, the creation of value for the consumer, trust in the company services, brand, attraction and retention of human talent, inclusion of social and environmental measures, metrics and financial reports of companies, which facilitate obtaining a significant increase in the level of growth (Aksoy et al., 2019).

In addition, the benefits of social innovation for service companies, according to the World Economic Forum (2016) are, among others, restoring customer confidence in business, adapting to resource scarcity and 
environmental concerns, attracting and retaining top talent, track and report on changing performance metrics, and growth and inclusion at scale, representing an excellent opportunity for service companies to significantly increase their level of growth from customer trust, recruit and reduce human resource turnover costs and implement new environmental, social and governance performance evaluation metrics (Aksoy et al., 2019).

In this sense, "social innovation is an essential factor in terms of fostering sustainable business growth, ensuring employment and increasing competitive capacities, particularly in the midst of an economic crisis and financial markets" (Aksoy et al. , 2019, p. 437). Furthermore, social innovation is considered in the scientific literature as necessary to act as an engine in the face of crises, determining "in what kind of world will the next generation of citizens of free societies live (Howaldt \& Schwarz, 2010, p. 18), and driving economic growth through the value chain for service companies (Aksoy et al., 2019). Thus, according to the information presented previously, the following research hypothesis is proposed:

H2: Social innovation has a significantly positive relationship with growth.

\section{Methodology}

To respond to the two research hypotheses, an empirical study was carried out in the service companies of the state of Aguascalientes (Mexico), for which the business directory of the Mexican Business Information System (SIEM) for the state was used. of Aguascalientes of 2019, which had a registry as of May 30 of 1,350 companies. In addition, an information collection instrument was designed that was applied to the managers of the companies, and it was applied to a sample of 300 service companies selected through a simple random sampling with an error of $\pm 5 \%$ and a level of significance $95 \%$, representing this sample a little more than $22 \%$ of the total population under study, and the survey was applied during the months of May to July 2019.

On the other hand, to measure social innovation, an adaptation of the scale of Pot and Vaas (2008) was carried out, who considered that it can be measured through 12 items. In addition, to measure innovation in services, an adaptation was made to the OECD scale (2005), who considered that it is possible to measure it by means of 7 items. Finally, to measure the growth of the companies, the sales made by the companies in 2019 were used (Autio et al., 1998; Ballow et al., 2004; Salojärvi et al., 2005; Linder, 2006; Carneiro, 2007; Kruger \& Johnson, 2009), since to estimate the growth potential that companies may have, a qualitative evaluation of managers is generally considered, with sales being the main indicator for its measurement (Autio et al., 1998). All the items of the three scales were measured through a 5 -point Likert-type scale with $1=$ totally disagree to $5=$ totally agree as limits, since this type of scale provides a balance between the complexity of the interviewees and Analysis of information (Forza, 2016; Hair, Celsi, Money, Samouel, \& Page, 2016).

Regarding the measurement of the reliability and validity of the three scales used, a Confirmatory Factor Analysis (CFA) was applied using the maximum likelihood method with the support of the SmartPLS 3.3 software (Hair et al., 2019), measuring the reliability using Cronbach's Alpha and the Composite Reliability Index (IFC) (Bagozzi et al., 2011). Thus, the results obtained from the AFC indicate that the Cronbach's Alpha and IFC values are higher than the recommended value of 0.7 , the items of the related factors of the social innovation and service innovation scales are significant $(\mathrm{p}<0.01)$, the value of all factor loadings are greater than 0.6 (Bagozzi et al., 2011), and the Index of the Extracted Variance (IVE) is greater than 0.5 (Fornell \& Larcker, 1981), which indicates the existence of reliability of the scales analyzed (Nunally \& Bernstein, 1994; Hair, Black, Babin, \& Anderson, 2014). Table 1 shows these results in greater detail.

Table 1. Reliability and convergent validity of the Social Innovation Model

\begin{tabular}{lccc}
\hline Variable & Cronbach Alpha & IFC & IVE \\
\hline Growth & 1.000 & 1.000 & 1.000 \\
Social Innovation & 0.943 & 0.951 & 0.619 \\
Service Innovation & 0.855 & 0.890 & 0.542 \\
\hline
\end{tabular}

Source: Own elaboration

Likewise, the valuation of the measurement scales of social innovation and service innovation commonly also include discriminant validity, which is generally measured in the literature through three elements: the Fornell and Larcker criterion, the cross loads and the Heterotrait-Monotrait ratio (HTMT) of correlations (Hair et al., 2019). Thus, when using the structural equation models with partial least squares (PLS-SEM), it was considered convenient to use the HTMT for the measurement of discriminant validity, since technically the HTMT is an 
estimate of what the real correlation would be. between the three constructs if they were measured in a perfect way, for which an HTMT value lower than 0.85 is recommended (Henseler, Ringle, \& Sarstedt, 2015). Table 2 shows that the values of social innovation, service innovation and growth are lower than the value of 0.85 recommended by Henseler et al. (2015).

Table 2. Discriminant validity (HTMT) of the Social Innovation Model

\begin{tabular}{lccc}
\hline Variables & Growth & Social Innovation & Service Innovation \\
\hline Growth & 0.160 & & \\
Social Innovation & 0.172 & 0.404 & \\
Service Innovation & &
\end{tabular}

Source: Own elaboration

\section{Results and Discussion}

In order to respond to the two research hypotheses that were raised in this empirical study, the application of a structural equation model with the support of the SmartPLS 3.3 software (Hair et al., 2019) was considered pertinent, analyzing, in In the first instance, the nomological validity of the model of social innovation, service innovation and the growth of Mexican service companies through the Chi-square test, by means of which the results obtained between the model were compared theoretical and the measurement model obtaining non-significant results, which allows establishing an excellent correlation between the three analyzed constructs (Hair et al., 2019) and, secondly, the relationship between the third factors through the generation of a nomogram. Figure 1 more clearly shows the results obtained.

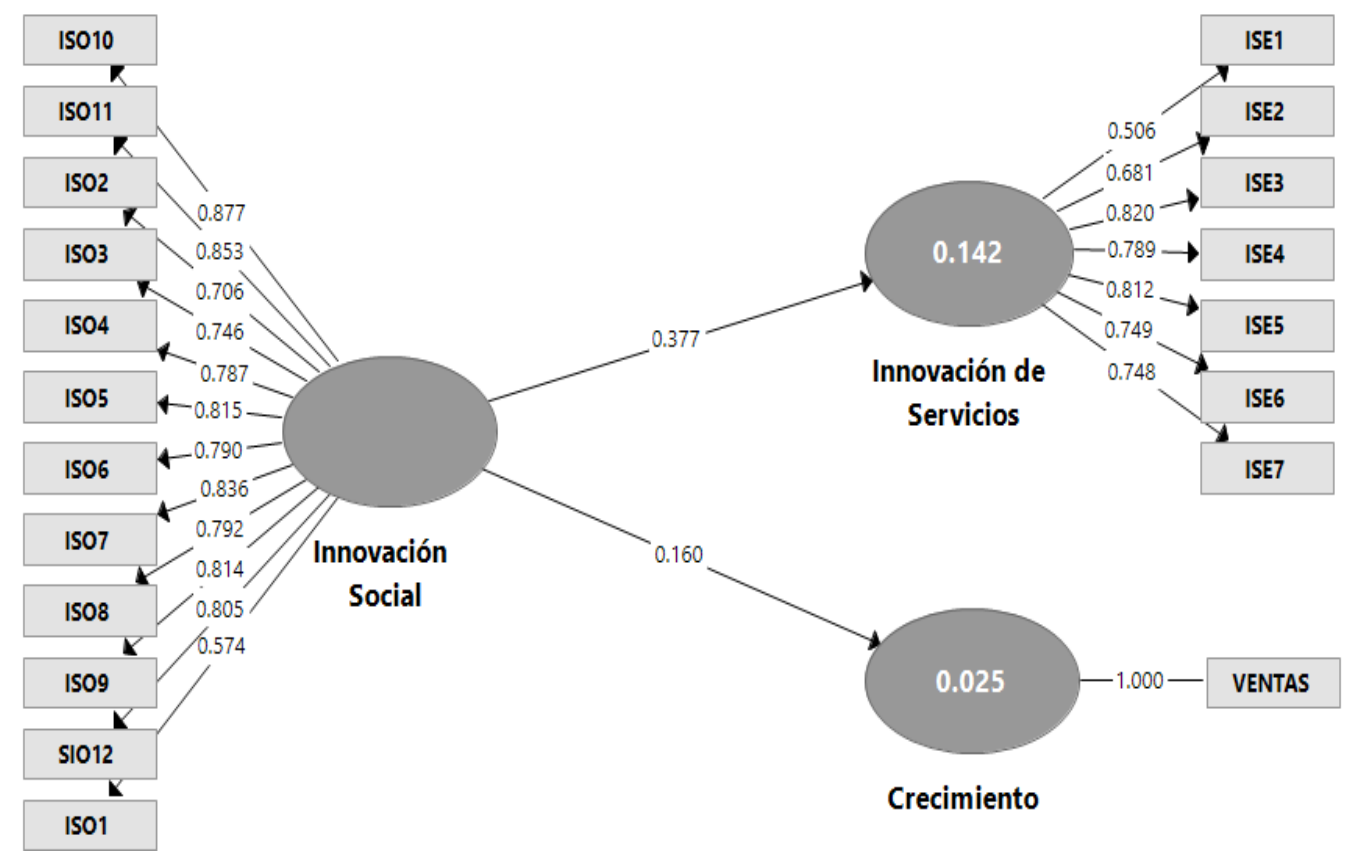

Figure 1. Nomogram of the PLS-SEM application

Source: Own Elaboration

Figure I shows that all the values of the standardized factor loadings of the social innovation and service innovation scales have a value greater than 0.6 , which indicates the existence of internal reliability of the two scales (Hair et al., 2019) . However, in growth it is not possible to obtain a standardized factor load greater than 0.6 , because it was measured with only one item. In addition, the same figure also shows the value of the relationships $(0.377 ; 0.160 ; \mathrm{p}<0.01)$, which indicate that social innovation has significant positive effects on service innovation and on the level of growth of companies services of Mexico. Likewise, to be sure that the data on the relationship between these three constructs are significant, it is necessary to review the data from the 
confidence interval of the HTMT by applying bootstrapping. (Dijstra \& Henseller, 2015).

Table 3. Bootstrapping confidence intervals of the Social Innovation Model

\begin{tabular}{lccccc}
\hline Variables & $\begin{array}{c}\text { Original } \\
\text { Sample (O) }\end{array}$ & Sample Mean (M) & Bias & $2.5 \%$ & $97.5 \%$ \\
\hline Social Innovation $\rightarrow$ Growth & 0.160 & 0.177 & 0.018 & 0.097 & 0.259 \\
Social Innovation $\rightarrow$ Service Innovation & 0.377 & 0.386 & 0.009 & 0.256 & 0.482 \\
\hline
\end{tabular}

Source: Own Elaboration

Table 3 shows the values of the confidence interval of the HTMT at $2.5 \%$ and $97.5 \%$ in the bootstrapping analysis, and it can be observed that the value of 1 is not found in both the lower and upper intervals, which indicates the existence of the stability of the estimation of the coefficient of the relationship between the three constructs analyzed (Dijkstra et al., 2015). In this sense, these results indicate that Mexican service companies should focus their efforts on increasing social innovation activities, particularly with their main commercial partners, so that they have greater possibilities of significantly increasing service innovation activities and their growth level.

In addition, these results have several implications for both managers and service companies, the first of which is related to the data obtained from the application of the 300 surveys, which allowed a robust analysis of the existing relationship between innovation social, service innovation and the level of growth in one of the most important sectors for the Mexican economy (the services sector), for which in future studies it would be important to analyze these same three constructs in successful case studies, or in longitudinal studies. Therefore, in the literature in the field of innovation, it is not surprising that researchers, academics and industry professionals establish that social innovation activities are becoming one of the determining agents of service innovation. (D'amario \& Comini, 2020).

A second implication derived from the results obtained is that social innovation has a significantly greater positive influence on service innovation than on the level of growth of service companies, as had been suggested by previous studies (Aksoy et al., 2019; Vanderhoven et al., 2020; Desmarchelier et al., 2020). For this reason, social innovation plays a fundamental role in service companies since when social innovation activities are significantly increased, it is more likely that service innovation activities will also increase, which will allow this type of companies substantially improve their level of growth and are more likely not only to remain in the market but also to increase their market share.

A third implication emanating from the results obtained is that a considerable part of the scarce studies published in the innovation literature have been essentially oriented towards the analysis and discussion of social innovation in highly industrialized and developed countries, leaving aside practically its analysis in emerging or developing economy countries. Therefore, it is important to establish that the service sector is one of the main sources of income for the majority of the population and is one of the most important sectors in the economy of this type of country, for which it is of the utmost importance that Researchers, academics and industry professionals guide their studies and research in the analysis and discussion of the effects of social innovation in the activities of service innovation.

A fourth and final implication derived from the results obtained is that even though the adoption and implementation of social innovation requires the realization of various changes in service companies, it is essential that service companies involve in service innovation activities to its main commercial partners, since this would not only facilitate the implementation of the required changes but also the obtaining of better business results, including a higher level of growth. In this sense, it is not surprising that social innovation is becoming a substantial activity that more and more service companies around the world are implementing in order to improve both their service innovation activities and their level of business growth.

\section{Conclusions}

The results obtained in this study allow us to establish various conclusions, among which the following stand out. A first conclusion is that the estimated theoretical model has a high internal consistency, since it generated a high correlation between social innovation, service innovation and the level of growth of service companies, which allowed the acceptance of the two hypotheses research raised. A second conclusion is that the same estimated model allowed an overview of the main activities of social innovation and service innovation, which facilitated 
the contribution of theoretical knowledge about the importance of the three analyzed constructs, as well as the contribution of robust empirical evidence of the effects of social innovation on both service innovation and growth.

A third conclusion is that the studies published in the innovation literature that analyze and discuss the relationship between social innovation, service innovation activities and the level of growth of service companies, are relatively scarce compared to those studies that have focused on the conceptualization of social innovation and service innovation (D'Amario et al., 2020), which from our point of view lack a substantial contribution to the development of knowledge, as they do not generate empirical evidence that allows contrasting the effects that social innovation has on service innovation activities, as well as that it can generate a comparison with the results previously obtained in the literature and establish the degree of influence of social innovation on service innovation.

A fourth conclusion is that the analysis of the relationship between social innovation, service innovation and the level of growth in service companies is a relatively recent topic in the innovation literature. However, even when this topic is gaining the attention of researchers, academics and industry professionals, it is possible to conclude that this topic is unfinished and open to discussion (D'Amario et al., 2020). Finally, a fifth conclusion is that the analysis and discussion of the relationship of social innovation, service innovation and the level of growth of service companies in emerging economy countries, such as Mexico, has not been explored in the current innovation literature, for which this study provides empirical evidence and new knowledge of the relationship between these three constructs.

\section{References}

Afriyie, S., Du, J., \& Abdul-Azzis, I. M. (2019). Innovation and Marketing Perfomance of SME in an Emerging Economy: The Moderating Effect of Transformational Leadership. Journal of Global Entrepreneurship Research, 9(40), 1-25. https://doi.org/10.1186/s40497-019-0165-3

Aksoy, L., Alkire (née Nasr), L., Choi, S., Kim, P. B., \& Zhang, L. (2019). Social Innovation in Service: A Conceptual Framework and Research Agenda. Journal of Service Management, 30(3), 429-448. https://doi.org/10.1108/JOSM-11-2018-0376

Auttio, E., \& Lumme, A. (1998). Does the innovator role affect the perceived potential for growth? Analysis of four types of new, technology-based firms. Technology Analysis \& Strategic Management, 10(1), 41-54. https://doi.org/10.1080/09537329808524303

Bagozzi, R., Yi, Y., \& Philipps, L. (1991). Assessing construct validity in organizational research. Administrative Science Quarterly, 36(1), 421-458. https://doi.org/10.2307/2393203

Ballow, J. J., McCarthy, B., \& Molnar, M. J. (2004). New Concepts in Value-Based Management: TRS Mapping and Total Economic Profit. Wellesley, USA: Accenture Institute for High Performance Business.

Baumol, W. J. (2002). Entrepreneurship, Innovation and Growth: The David-Goliath Symbiosis. Journal of Entrepreneurial Finance, 7(2), 1-10. Abstract retrieved from https://citeseerx.ist.psu.edu/viewdoc/download?doi=10.1.1.1027.202\&rep=rep1\&type=pdf

Bureau of European Policy Advisers. (2010). Empowering People, Driving Change: Social Innovation in the European Union, Bruselas: Comisión Europea.

Carneiro, A. (2007). What is required for growth? Business Strategy Series, 8(1), 51-57. https://doi.org/10.1108/17515630710686888

D'amario, E. Q., \& Comini, G. M. (2020). Social Innovation in Brazilian Social Entrepreneurships: A Proposed Scale for its Classification. Revista Brasileira de Gestão de Negócios, 22(1), 104-122. https://doi.org/10.7819/rbgn.v22i1.4037

Damanpour, F. (1991). Organizational Innovation: A Meta-Analysis of Effects of Determinants and Moderators. Academy of Management Journal, 34(3), 555-590. https://doi.org/10.5465/256406

Davis, G. F., \& White, C. J. (2015). Changing Your Company from the Inside Out: A Guide for Social Intrapreneurs. Boston: Harvard Business Review Press.

Desmarchelier, B., Djellal, F., \& Gallouj, F. (2020). Mapping Social Innovation Networks: Knowledge Intensive Social Services as Systems Builders. Technological Forecasting and Social Change, 157(120068). https://doi.org/10.1016/j.techfore.2020.120068

Dijstra, T., \& Henseller, J. (2015). Consistent partial least squares path modeling. MIS Quarterly, 39(2), 
297-2316. https://doi.org/ 10.25300/MISQ/2015/39.2.02

Fornell, C., \& Larcker, D. F. (1981). Evaluating structural equation models with unobservable variables and measurement error. Journal of Marketing Research, 18(1), 39-50. https://doi.org/10.2307/3151312

Forza, C. (2016). Surveys, In: Christer Karlsson (Ed.), Research Methods for Operations Management (2nd ed.). New York, NY: Routledge.

Hair, J. F, Celsi, M. W., Money, A. H., Samouel, P., \& Page, M. J. (2016). Essentials of Business Research Methods (3rd ed.). New York, NY: Routledge.

Hair, J. F., Black, W. C., Babin, B. J., \& Anderson, R. E. (2014). Multivariate Data Analysis (7th ed.). Harlow, UK: Pearson Education. https://doi.org/10.4324/9781315704562

Hair, J., Hult, T., Ringle, C., Sarstedt, M., Castillo, J., Cepeda, G., \& Roldán, J. L. (2019). Manual de Partial Least Squares PLS-SEM (2nd ed.). Madrid: OmniaScience.

Henseler, J., Ringle, C., \& Sarstedt, M. (2015). A new criterion for assessing discriminant validity in variance-based structural equation modeling. Journal of the Academy of Marketing Science, 43(1), 115-135. https://doi.org/10.1007/s11747-014-0403-8

Howaldt, J., \& Schwarz, M. (2010). Social Innovation: Concepts, Research Fields and International Trends: IMA/ZLW. Open Journal of Social Sciences, 4(5).

Kraus, S., Niemand, T., Halberstadt, J., Shaw, E., \& Syrja, P. (2017). Social Entrepreneurship Orientation: Development of a Measurement Scale. International Journal of Entrepreneurial Behavior \& Research, 23(6), 977-997. https://doi.org/10.1108/IJEBR-07-2016-0206

Kruger, C. J., (Neels) \& Johnson, R. D. (2009). Assessment of knowledge management growth: A South Africa perspective, Aslib Proceedings, New Information Perspectives. Aslib Proceedings, 61(6), 542-564. https://doi.org/10.1108/00012530911005517

Linder, J. C. (2006). Does innovation drive profitable growth? New metrics for a complete picture. Journal of Business Strategy, 27(5), 38-44. https://doi.org/10.1108/02756660610692699

Millar, S. R., Steiner, A., Caló, F., \& Teasdale, S. (2020). COOL Music: A 'Bottom-up' Music Intervention for Hard-to-Reach Young People in Scotland. British Journal of Music Education, 37(1), 87-98. https://doi.org/10.1017/S0265051719000226

Montgomery, T. (2016). Are Social Innovation Paradigms Incommensurable? International Journal of Voluntary and Nonprofit Organizations, 27(4), 1979-2000. https://doi.org/10.1007/s11266-016-9688-1

Naciones Unidas. (2020a). Objetivos de Desarrollo Sostenible. La Agenda para el Desarrollo Sostenible, Ginebra.

Naciones Unidas. (2020b). Informe de los Objetivos de Desarrollo Sostenible. Naciones Unida, Ginebra.

Nunally, J. C., \& Bernstein, I. H. (1994). Psychometric Theory (3rd ed.). New York, NY: McGraw-Hill.

Organisation for Economic Co-Operation and Development. (2005). Oslo Manual: Guidelines for Collecting and Interpreting Innovation Data (3rd ed.). OECD, Eurostat.

Organisation for Economic Co-Operation and Development. (2005). Oslo Manual: Guidelines for collecting and interpreting innovation data, In OECD (Ed.), The Measurement of Scientific and Technological Activities, Paris: OECD Publishing, pp. 235-250.

Organisation for Economic Co-Operation and Development. (2009). Innovación Regional en 15 Estados Mexicanos, OECD, Eurostat.

Organisation for Economic Co-Operation and Development. (2010). SMEs, Entrepreneruship and Innovation, OECD, Eurostat.

Phillips, W., Lee, H., Ghobadian, A., O'regan, N., \& James, P. (2015). Social Innovation and Social Entrepreneurship: A Systematic Review. Group \& Organization Management, 40(3), 428-461. https://doi.org/10.1177/1059601114560063

Pot, F., \& Vaas, F. (2008). Social innovation, the new challenge for Europe. International Journal of Productivity and Performance Management, 57(6), 468-473. https://doi.org/10.1108/17410400810893400

Reilly, J. M. (2012). Green Growth and the Efficient Use of Natural. Resources. Energy Economics, 34(1), S85-S93. https://doi.org/10.1016/j.eneco.2012.08.033 
Salojarvi, S., Furu, P., \& Sveiby, K. E. (2005). Knowledge management and growth in finish SMEs. Journal of Knowledge Management, 9(2), 103-122. https://doi.org/10.1108/13673270510590254

Sinthupundaja, J., Kohda, Y., \& Chiadamrong, N. (2019). Examining Capabilities of Social Entrepreneurship for Share Value Creation. Journal of Social Entrepreneurship, 1-23. https://doi.org/10.1080/19420676.2018.1543726

Soma, K., Van de Burg, S. W. K., Hoefnagel, E. W.J., Stuiver, M., Van der Heide, \& C. Martijn. (2018). Social Innovation- A Future Pathway for Blue Growth? Marine Policy, 87, 363-370. https://doi.org/10.1016/j.marpol.2017.10.008

Vanderhoven, E., Steiner, A., Teasdale, S., \& Calò, F. (2020). Can Public Venture Capital Support Sustainability in the Social Economy? Evidence from a Social Inovation Fund. Journal of Business Venturing Insights, 13, e00166. https://doi.org/10.1016/j.jbvi.2020.e00166

World Economic Forum. (2016). Social Innovation a Guide to Achieving Corporate and Societal Value. Schwab Foundation for Social Entrepreneurship. Abstract retrieved from http://www3.weforum.org/docs/WEF_Social_Innovation_Guide.pdf

\section{Copyrights}

Copyright for this article is retained by the author(s), with first publication rights granted to the journal.

This is an open-access article distributed under the terms and conditions of the Creative Commons Attribution license (http://creativecommons.org/licenses/by/4.0/). 